\title{
Evaluation of stress in laboratory rabbits used for teaching purposes
}

\author{
Monika Urbanova $^{1}$, Eva Kramarova ${ }^{2}$, Jan Chloupek ${ }^{2}$, Martina Najmanova ${ }^{2}$ \\ University of Veterinary and Pharmaceutical Sciences Brno, ${ }^{1}$ Faculty of Veterinary Hygiene and Ecology, \\ Department of Veterinary Public Health and Forensic Medicine, ${ }^{2}$ Faculty of Veterinary Medicine, \\ Department of Pharmacology and Pharmacy, Brno, Czech Republic \\ Received November 14, 2018 \\ Accepted April 23, 2019
}

\begin{abstract}
This study was intended as a contribution to the argument about possible suffering of animals used for demonstrative purposes during teaching at universities. Pharmacology lectures at the University of Veterinary and Pharmaceutical Sciences Brno, Czech Republic were selected for this experiment. The study focused on stress assessment using haematological and biochemical indices. Blood samples were drawn from 20 rabbits (Oryctolagus cuniculus f. domesticus L.) 10 days after arrival at the institute (before the first practical lesson), and then in the $7^{\text {th }}$ and $12^{\text {th }}$ weeks of the semester with practical lessons. The haematological and biochemical indices were compared between the experimental group $(n=10)$ used for practical demonstrations and the control group $(n=10)$ which was kept in its hutch. Practical lessons included manipulation with rabbits, health examination, topical or total application and observation of the drugs' effects. All the acts were carried out by students. Significant changes were detected in some of haematological (erythrocytes, haemoglobin, haematocrit) and biochemical (glucose, total protein, enzymes aspartate aminotransferase and lactate dehydrogenase) variables compared to the control group. The values obtained from the last blood sampling indicate a possible habituation process in the experimental group between the $8^{\text {th }}$ and $12^{\text {th }}$ week. The results were compared between the experimental and control group and also with the results of other studies with different stressors. In conclusion, the stress the rabbits used for teaching purposes at universities are exposed to, is tolerable.
\end{abstract}

Animal stress, haematological indices, biochemical properties, glucose, total protein

Our study was intended as a contribution to the ongoing discussion about the level of stress in animals used for research and teaching demonstrations at universities. For this type of study, there is no classic stress model that could be applied which has led to a lack of studies and reference values in this field. Rabbits are used as laboratory animals very often and they are suitable model organisms for teaching purposes, too. Practical lessons have often been conducted using rabbits.

Stress is the organism's response to a stimulus which leads to activation of the hypothalamic-pituitary-adrenocortical axis (HPA) and the sympatho- adrenomedullary system (Möstl and Palme 2002). Both chains of hormonal reactions influence the adrenal glands and the glucocorticoids that are excreted lead to many hormonal changes and changes in the metabolic status (Möstl and Palme 2002). The main effect of elevated glucocorticoid concentrations (cortisol and corticosterone) is an increase in the glucose level (Möstl and Palme 2002; Romero 2004; Grissom and Bhatnagar 2009). Glucose and cortisol are designated markers of acute stress in humans and animals (Armario et al. 1996; Romero 2004; Breinekova et al. 2007). However, severe chronic stress (prolonged periods of high cortisol concentrations in the blood stream and their long term effect) may negatively influence the overall health condition (Möstl and Palme 2002; Grissom and Bhatnagar 2009) which is why concentrations of these hormones are used as health and welfare indicators. The stress reaction can alter many haematological and biochemical indices which is why the least invasive method for sample collection was

\footnotetext{
Address for correspondence: 
chosen. In the event of a more pronounced chronic stress, not only do the haematological and biochemical indices change, but the overall health condition is also affected, e.g. by reduction of feed intake and weight loss (Cabezas et al. 2007; Okab et al. 2008).

The main aim of the study was to objectively determine the possible degree of stress impact on the rabbits caused by manipulation during practical lessons. The other aim was to determine whether the haematological and biochemical indices were affected in the long term. Our intention was to contribute an objective argument to the discussion about the possible suffering of animals used for demonstration purposes in practical lessons.

\section{Materials and Methods}

Twenty New Zealand white rabbits (Oryctolagus cuniculus f. domesticus L.) from a commercial breeding farm (Lapins s.r.o., Dolní Dubňany, Czech Republic) were used. They were 6 weeks old at the beginning of the experiment. The rabbits were housed individually in stainless steel cages but they could see each other. Each cage was marked by a number. The rabbits were kept under controlled environmental conditions, and their biorhythm was set to $12 \mathrm{~h}$ of light and $12 \mathrm{~h}$ of dark. The temperature was kept between 17 and $23{ }^{\circ} \mathrm{C}$ and the humidity was between $45 \%$ and $60 \%$. The rabbits were checked on every day. Feed and water were provided ad libitum. The complete feed mixture for all the rabbits, Biostan KBO (Biokron s.r.o., Blučina, Czech Republic), consisted of pellets, oats and other grains. Cleaning of the hutches was performed every 3 days or, when necessary, more frequently.

This study was carried out during pharmacology lectures at the University of Veterinary and Pharmaceutical Sciences Brno, Czech Republic. The study was conducted over the 12 weeks of the winter semester. Twenty rabbits were divided into two groups, an experimental $(n=10)$ and a control group $(n=10)$. The control group was kept constantly in cages except during routine maintenance tasks. Selected rabbits from the experimental group and other rabbits (which were not included into the study) were repeatedly used during practical lessons. There were 50 rabbits in total in the facility. Ten of them were randomly chosen as the experimental group and other 10 rabbits were chosen as the control group. This selection was done before the study started. In each practical lesson, 8 rabbits were used, which meant that rabbits of the experimental group were used 2 or 3 times a week like the other rabbits.

The rabbits selected for the experimental group were transported from the housing facilities into individual cages in the classroom before the lesson began. The basic examination of the rabbits' health condition was performed by students at the beginning of every lesson. This examination consisted of measuring the pulse, heart rate, and temperature. All procedures that were carried out on the rabbits by students during the semester are listed in Table 1. The below mentioned substances were applied according to the instructions and then the therapeutic effect of the substance was observed or measured. During these procedures, the rabbits were usually fixated with towels. Every rabbit was returned into the cage after the end of the practical act. They were housed in the cages in the classroom during lessons which lasted $4 \mathrm{~h}$.

Table 1. Practical procedures on rabbits during the study.

\begin{tabular}{ll}
\hline Week of semester & Practical procedures according to the syllabus of practical lessons \\
\hline $1^{\text {st }}$ and $2^{\text {td }}$ & manipulation, fixation, basic examination \\
\hline $3^{\text {rd }}$ and $4^{\text {th }}$ & 4 drops of $0.5 \%$ atropini sulfas \\
Intraconjunctival drops & 4 drops of $0.5 \%$ physostigmini salicylas \\
application & 4 drops of $1 \%$ physostigmini salicylas \\
\hline $5^{\text {th }}$ and $6^{\text {th }}$ & $1 \mathrm{mg} / \mathrm{ml}$ epinefhrini hydrochloridum $0.1 \mathrm{ml}$ intramuscular \\
Local anaestesia & $1 \mathrm{mg} / \mathrm{ml}$ epinefhrini hydrochloridum $5 \mathrm{mg} / \mathrm{kg}$ intramuscular \\
Intraconjunctival drops & 6 drops of $1.0 \%$ cocaini hydrochloridum \\
application or intramuscular & 6 drops of $1.0 \%$ procaini hydrochloridum \\
application & $1 \%$ solution morphini hydrochloridum, $5 \mathrm{mg} / \mathrm{kg}$ sub cutis \\
\hline $7^{\text {th }}$ and $8^{\text {th }}$ & Inhalation anaesthesia - isoflurane, premedication medetomidini \\
$9^{\text {th }}$ and $10^{\text {th }}$ & hydrochloridum $1 \mathrm{mg}-0.12$ ml pro toto, $\mathrm{ketamine} 5 \mathrm{mg} / \mathrm{kg}$ \\
Anaesthesia $^{\text {th }}$ & Intravenous anaesthesia $-2.5 \%$ thiopental $20 \mathrm{mg} / \mathrm{kg}$ \\
\hline $11^{\text {th }}$ and $12^{\text {th }}$ & manipulation, fixation, basic examination, blood sampling $0.5 \mathrm{ml}$ \\
\hline
\end{tabular}


This experimental project was approved by the Animal Use Committee of the University of Veterinary and Pharmaceutical Sciences Brno no. PP 31-2017 and was in compliance with the national legislation (Act No. 246/1992 Coll., on the Protection of Animals Against Cruelty, as amended and Decree No. 419/2012 Coll., on the Protection of Experimental Animals, as amended).

Both groups of rabbits had their blood collected three times. The first sampling was done ten days after they were acclimated to the new conditions and before the first practical lesson. The second sampling was done in the $7^{\text {th }}$ week of the semester, and the third sampling was done in the $12^{\text {th }}$ week of the semester.

Every rabbit was taken from its cage by hand and wrapped in a towel on the sampling table. Their keepers manipulated and fixated them, and blood was always collected without sedation. Daily rhythms did not affect the results because the sampling was done between 8:00 and 9:00 h. Ethyl alcohol was applied to dissinfect the collection site and 1.5 millilitres of blood were obtained from the vena auricularis marginalis of each rabbit. The blood was collected into two commercial tubes (Dispolab s.r.o., Brno, Czech Republic), first into a tube with EDTA (ethylenediaminetetraacetic acid) for haematology and then into one containing amorphous heparin for biochemical examination. After collecting blood samples from both groups, the samples were transported to the university laboratory where they were immediately analysed.

All samples were analysed for a complete blood count. Haematological indices such as the amount of erythrocytes (Ery), leukocytes (Leu), thrombocytes (Throm) and haemoglobin (Hb) was done by the haematological analyser Sysmex XT-2000iV (Sysmex, Kobe, Japan). From these values, other indices were calculated such as haematocrit (Ht) and red blood cell indices such as the mean corpuscular volume (MCV), mean corpuscular haemoglobin $(\mathrm{MCH})$ and mean corpuscular haemoglobin concentration $(\mathrm{MCHC})$. The manual evaluation differential of leucocytes from the blood stains with Hemacolor was done by the microscope Olympus, type BX51TF (Olympus, Prague, Czech Republic).

The blood samples in the tubes with amorphous heparin were centrifuged (at $800 \mathrm{~g}$ for $5 \mathrm{~min}$ ). Biochemical tests of the blood plasma were performed to obtain the following indices: total protein, albumin, glucose, aspartate aminotransferase (AST), alanine aminotransferase (ALT) and lactate dehydrogenase (LDH). The measurement was done by the analysator ABBOTT Architect c4000 (ABBOTT, Princeton, New Jersey, USA) with a photometric determination.

The rest of the plasma samples were placed in Eppendorf tubes and frozen at $-80{ }^{\circ} \mathrm{C}$, and later used for hormone analysis. Corticosterone concentration was measured by an enzyme immunoassay commercial kit (Corticosterone StressXpress EIA Kit StressMarq Biosciences Inc., Victoria, BC Canada). Sensitivity of this test was determined as $18.6 \mathrm{pg} / \mathrm{ml}$ and detection limit was determined as $16.9 \mathrm{pg} / \mathrm{ml}$. Photometric measurement of colour intensity was performed on the calorimetric reader at a wavelength of $450 \mathrm{~nm}$. The results were determined after reading from the standard curve which was proposed in the programme free ELISA Software (Elysaanalysis.com).

Determination of cortisol in blood plasma was measured by liquid chromatography with tandem mass spectrometry (LC/MS/MS). The Thermo Scientific UHPLC Accela 1250 system was connected to the Thermo Scientific TSQ Quantum Access MAX Triple Quadrupole Instrument (Thermo, San Jose, CA, USA) equipped with a heated electrospray ionization (HESI-II) probe. The mobile phase consisted of water containing $0.1 \%$ formic acid $(\mathrm{v} / \mathrm{v})$ and acetonitrile containing $0.1 \%$ formic acid. Cortisol was separated by an isocratic elution method. The heated electrospray ionization was operated in positive-ion mode. The detection limit for cortisol was $2,000 \mathrm{pg} / \mathrm{ml}$.

Some plasma cortisol and corticosterone reference values are listed in Table 2. It is difficult to determine the basal values of these hormones, because any interference before blood sampling may affect them.

All statistical analyses were performed using the statistical software UNISTAT for Excel version 6 . The tests of normality were carried out in the first phase. The values of the corresponding Gauss curve were evaluated by $t$-test, non-parametric values were evaluated by Mann-Whitney's test.

Table 2. Selected plasma corticol and corticosterone reference values and maximal and minimal value influenced by the daily rhytm as determined for rabbits.

\begin{tabular}{llll}
\hline Glucocorticoid hormone values & & Condition & \multicolumn{1}{c}{ Study } \\
\hline Cortisol & & & \\
\hline Reference values & $2.60-3.80 \mu \mathrm{g} / \mathrm{dl}$ & & Washington and Van Hoosier 2012 \\
Minimal & $0.33 \mu \mathrm{g} / \mathrm{dl}$ & at $6: 00 \mathrm{~h}$ & Szeto 2003 \\
Maximal & $0.92 \mu \mathrm{g} / \mathrm{dl}$ & at $12: 00 \mathrm{~h}$ & \\
\hline Corticosterone & & \\
\hline Reference value & $1.54 \mu \mathrm{g} / \mathrm{dl}$ & Washington and Van Hoosier 2012 \\
Baseline values & $1.52 \pm 0.52 \mu \mathrm{g} / \mathrm{dl}$ & & Rosenthal 2000 \\
Minimal & $14.25 \mathrm{ng} / \mathrm{ml}$ & at $6: 00 \mathrm{~h}$ & Szeto 2003 \\
Maximal & $30.01 \mathrm{ng} / \mathrm{ml}$ & at 6:00 h & \\
\hline
\end{tabular}


Differences were considered to be significant when the probability of the null hypothesis was less than 0.05 (i.e., $P<0.05)$ and highly significant if the probability of the null hypothesis was less than 0.01 (i.e., $P<0.01$ ). The average values of the experimental group and the control group were compared within one sampling.

Table 3. Haematological indices in rabbits of the control $(n=10)$ and the experimental group $(n=10)$.

\begin{tabular}{|c|c|c|c|c|c|c|}
\hline & \multicolumn{2}{|c|}{ First sampling } & \multicolumn{2}{|c|}{ Second sampling } & \multicolumn{2}{|c|}{ Third sampling } \\
\hline & $\begin{array}{l}\text { Control } \\
\text { group }\end{array}$ & $\begin{array}{l}\text { Experimental } \\
\text { group }\end{array}$ & $\begin{array}{l}\text { Control } \\
\text { group }\end{array}$ & $\begin{array}{l}\text { Experimental } \\
\text { group }\end{array}$ & $\begin{array}{l}\text { Control } \\
\text { group }\end{array}$ & $\begin{array}{l}\text { Experimental } \\
\text { group }\end{array}$ \\
\hline Leu $\times 10^{9} / 1$ & $9.16 \pm 1.43$ & $10.22 \pm 2.83$ & $10.88 \pm 2.14$ & $9.16 \pm 2.93$ & $11.26 \pm 2.22$ & $10.43 \pm 4.12$ \\
\hline Ery $\times 10^{12} / 1$ & $6.49 \pm 0.73$ & $6.27 \pm 0.37$ & $6.62 * \pm 0.59$ & $6.02 * \pm 0.62$ & $6.45^{*} \pm 0.60$ & $5.88 * \pm 0.38$ \\
\hline $\mathrm{Hb} g / \mathrm{l}$ & $129.50 \pm 7.80$ & $126.86 \pm 6.39$ & $134.60 \pm 8.25$ & $125.88 \pm 10.22$ & $136.20 * \pm 8.92$ & $127.89^{*} \pm 6.51$ \\
\hline $\mathrm{Ht}$ l/1 & $0.41 \pm 0.02$ & $0.39 \pm 0.02$ & $0.41 * \pm 0.02$ & $0.37^{*} \pm 0.04$ & $0.43^{* *} \pm 0,02$ & $0.40 * * \pm 0.02$ \\
\hline Thrombocytes $\times 10^{9} / 1$ & $422.75 \pm 173.08$ & $341.14 \pm 138.35$ & $370.20 \pm 86.78$ & $367.88 \pm 113.11$ & $369.20 \pm 92.76$ & $331.38 \pm 136.74$ \\
\hline Neutrophils $\times 10^{9} / 1$ & $2.85 \pm 0.78$ & $3.79 \pm 2.10$ & $3.21 \pm 1.03$ & $2.81 \pm 1.93$ & $2.59 \pm 1.03$ & $2.92 \pm 2.18$ \\
\hline Lymphocytes $\times 10^{9} / 1$ & $4.80 \pm 0.92$ & $4.93 \pm 1.0$ & $6.13 \pm 1.53$ & $5.21 \pm 1.13$ & $6.95 \pm 1.74$ & $5.76 \pm 1.72$ \\
\hline Monocytes × $10^{9} / 1$ & $0.82 \pm 0.29$ & $0.85 \pm 0.29$ & $0.88 \pm 0.36$ & $0.55 \pm 0.33$ & $1.02 \pm 0.25$ & $0.93 \pm 0.61$ \\
\hline Eosinophils $\times 10^{9} / 1$ & $0.12 \pm 0.09$ & $0.10 \pm 0.07$ & $0.13 \pm 0.07$ & $0.19 \pm 0.20$ & $0.19 \pm 0.20$ & $0.21 \pm 0.20$ \\
\hline Basophils × $10^{9} / 1$ & $0.58 \pm 0.20$ & $0.56 \pm 0.33$ & $0.54 \pm 0.30$ & $0.40 \pm 0.15$ & $0.51 \pm 0.18$ & $0.61 \pm 0.26$ \\
\hline MCV fl & $63.26 \pm 5.11$ & $62.79 \pm 2.45$ & $63.85 \pm 4.11$ & $64.23 \pm 3.40$ & $66.25 \pm 4.67$ & $67.89 \pm 3.18$ \\
\hline $\mathrm{MCH} p g$ & $20.08 \pm 1.20$ & $20.27 \pm 0.78$ & $20.38 \pm 0.99$ & $21.08 \pm 1.07$ & $21.17 \pm 0.98$ & $21.92 \pm 0.87$ \\
\hline $\mathrm{MCHC} \mathrm{g} / \mathrm{l}$ & $317.75 \pm 7.40$ & $323.00 \pm 5.89$ & $324.70 \pm 7.35$ & $326.63 \pm 7.78$ & $320.00 \pm 8.31$ & $322.78 \pm 5.59$ \\
\hline
\end{tabular}

Leu - leukocytes, Ery - erythrocytes, $\mathrm{Hb}$ - haemoglobin, $\mathrm{Ht}$ - haematocrit, MCV - mean corpuscular volume, MCH - mean corpuscular haemoglobin, MCHC - mean corpuscular haemoglobin concentration

All values were expressed as the mean value \pm standard deviation. The mean values of the experimental and the control group were compared within one sampling period. ${ }^{*} P<0.05$ significant; ${ }^{*} P<0.01$ highly significant.

\section{Results}

The mean values of haematological indices are shown in Table 3. The erythrocyte count of animals of the experimental group was significantly lower $(P<0.05)$ compared to the control group in the second and third sampling.

Haematocrit mean values in rabbits of the experimental group were significantly lower $(P<0.05)$ compared to the control group after the second blood sampling, and highly significantly lower $(P<0.01)$ compared to control group after the third blood sampling.

Table 4. Biochemical indices in rabbits of the control $(n=10)$ and experimental group $(n=10)$.

\begin{tabular}{|c|c|c|c|c|c|c|}
\hline & \multicolumn{2}{|c|}{ First sampling } & \multicolumn{2}{|c|}{ Second sampling } & \multicolumn{2}{|c|}{ Third sampling } \\
\hline & $\begin{array}{l}\text { Control } \\
\text { group }\end{array}$ & $\begin{array}{c}\text { Experimental } \\
\text { group }\end{array}$ & $\begin{array}{l}\text { Control } \\
\text { group }\end{array}$ & $\begin{array}{c}\text { Experimental } \\
\text { group }\end{array}$ & $\begin{array}{l}\text { Control } \\
\text { group }\end{array}$ & $\begin{array}{c}\text { Experimental } \\
\text { group }\end{array}$ \\
\hline Total protein $\mathrm{g} / \mathrm{l}$ & $63.55 \pm 4.86$ & $60.35 \pm 3.09$ & $63.52 * \pm 5.42$ & $58.89 * \pm 2.45$ & $63.72 * \pm 5.48$ & $60.54 * \pm 2.05$ \\
\hline Albumin g/l & $30.70 \pm 2.47$ & $30.19 \pm 0.91$ & $32.32 \pm 2.44$ & $30.85 \pm 0.95$ & $33.02 \pm 3.34$ & $33.01 \pm 0.65$ \\
\hline Glucose $\mathrm{mmol} / \mathrm{l}$ & $6.98 \pm 0.83$ & $6.52 \pm 0.66$ & $7.75 * * \pm 0.60$ & $7.19 * * \pm 0.24$ & $8.51 \pm 0.75$ & $7.84 \pm 0.59$ \\
\hline ALT $\Perp \mathrm{kat} / \mathrm{l}$ & $0.78 \pm 0.31$ & $0.85 \pm 0.44$ & $0.73 \pm 0.33$ & $0.98 \pm 0.45$ & $0.71 \pm 0.38$ & $0.99 \pm 0.35$ \\
\hline AST $\underline{\mu k a t / l}$ & $0.33 \pm 0.09$ & $0.34 \pm 0.11$ & $0.26^{*} \pm 0.07$ & $0.36 * \pm 0.09$ & $0.26 \pm 0.08$ & $0.39 \pm 0.28$ \\
\hline $\mathrm{LDH} \underline{\mu} \mathrm{kat} / \mathrm{l}$ & $1.93 \pm 0.77$ & $2.16 \pm 1.03$ & $1.89^{*} \pm 0.53$ & $3.4^{*} \pm 2.33$ & $1.30 \pm 0.55$ & $1.52 \pm 0.85$ \\
\hline
\end{tabular}

ALT - alanine aminotransferase, AST - aspartate aminotransferase, LDH - lactate dehydrogenase

All values were expressed as the mean value \pm standard deviation. The mean values of the experimental and the control group were compared within one sampling period.

$* P<0.05$ significant; ${ }^{* *} P<0.01$ highly significant. 
Significantly lower $(P<0.05)$ differences were found between the mean haemoglobin values in rabbits of the experimental group compared to the control group after the third sampling. Other haematological indices were without significant differences.

The differences between biochemical indices and other mean values are listed in Table 4. Total protein values in animals of the experimental group were significantly lower $(P<0.05)$ than the control group values after the second and third blood sampling. A highly significant elevation of glucose $(P<0.01)$ was determined after the second sampling. The mean glucose value in the control group was higher compared to mean value of the experimental group, which was an unexpected result for this group. Aspartate aminotransferase was significantly increased $(P<0.05)$ in the experimental group compared to the control group after the second sampling. Also, the elevation of LDH activity in the experimental group was significant $(P<0.05)$ compared to the control after the second sampling.

Albumin and ALT values in rabbits were without significant differences $(P>0.05)$ during the experimental period.

The mean corticosterone value of both groups is presented in Table 5. The measured corticosterone values were low; the mean values were around $300 \mathrm{pg} / \mathrm{ml}$ and the highest value was $1,480 \mathrm{pg} / \mathrm{ml}$. The differences were non-significant. Plasma cortisol levels were below the cortisol detection limit, less than $2,000 \mathrm{pg} / \mathrm{ml}$.

Table 5. Mean values of corticosterone which were analysed after the first, second and third blood sampling.

\begin{tabular}{|c|c|c|c|c|c|c|}
\hline & \multicolumn{2}{|c|}{ First sampling } & \multicolumn{2}{|c|}{ Second sampling } & \multicolumn{2}{|c|}{ Third sampling } \\
\hline & $\begin{array}{l}\text { Control } \\
\text { group }\end{array}$ & $\begin{array}{c}\text { Experimental } \\
\text { group }\end{array}$ & $\begin{array}{l}\text { Control } \\
\text { group }\end{array}$ & $\begin{array}{c}\text { Experimental } \\
\text { group }\end{array}$ & $\begin{array}{l}\text { Control } \\
\text { group }\end{array}$ & $\begin{array}{c}\text { Experimental } \\
\text { group }\end{array}$ \\
\hline Corticosterone pg/ml & $265.58 \pm 72.17$ & $314.28 \pm 136.15$ & $229.34 \pm 50.00$ & $323.89 \pm 96.19$ & $147.15 \pm 37.18$ & $232.01 \pm 36.71$ \\
\hline
\end{tabular}

All values are expressed as the mean value \pm standard deviation.

\section{Discussion}

The aim was to find out whether the contact with students associated with practical lessons caused any stress effects in the rabbits.

The value of erythrocytes, haemoglobin and haematocrit were determined as indices that may vary depending on the duration of stress. Chronic stress results in a decrease in these indices (Okab et al. 2008; Everds et al. 2013). Wei et al. (2008) noted in their study that psychological stress in rats decreased the values of erythrocytes, haemoglobin and erythropoietin. Our study shows the same result, however, the values correspond to the reference range (Vella and Donnelly 2012; Knotkova et al. 2017). The loss of blood was minimal during the study. Our study did not show any significant changes in the leukocyte profiles.

The first sampling of our study was done when the rabbits were seven weeks old and the total protein and albumin values were normal and without significant differences. Total protein values in young rabbits are lower than in adults; rabbits older than 12 weeks achieve normal adult-like values (Melillo 2007). Values of the second and third samplings were significantly lower in the experimental group; the differences were especially evident in the second sampling. Reasons for reduction of protein are chronic malnutrition or loss of proteins (Melillo 2007). No health problems were observed during the study. At the end of the study, rabbits from both groups weighed about $4.5 \mathrm{~kg}$.

Total protein could be designated as a long-term stress indicator in rabbits, as a study of the effect of noise on rabbits showed significantly lower total protein values after 50 days of daily exposure (Elwasife et al. 2015) and another one reported that a higher concentration of rabbits in a cage also resulted in a reduction in protein values (Kalaba 2012). 
In our study, a higher concentration of glucose was determined in the control group during second sampling which was an unexpected outcome. It could have been triggered by unusual sounds in the room, by manipulation and fixation because the control group was not as used to these procedures as the experimental group which was used for demonstration purposes in practical lessons. The trend of gradual increase in glucose levels was observed in both groups during our study.

The level of glycaemia is considered a stress indicator in a number of other cases because many factors lead to the change of the glucose concentration in rabbits (Washington and Van Hoosier 2012), e.g. chronic noise exposure can cause a reduction (Elwasife et al. 2015) but heat stress (Składanowska-Baryza et al. 2018), higher concentration of rabbits in the cage (Kalaba 2012) or transport to slaughter (Składanowska-Baryza et al. 2018) can cause its elevation. Transport and manipulation in the laboratory can increase the glucose concentration (and other variables) in laboratory rats (Castelhano-Carlos and Baumans 2009).

It is assumed that the increase of enzymes AST and LDH in the second sampling in our study was due to repeated stress in the experimental group. Later during the third sampling, no differences were found, presumably due to the experimental group becoming used to the manipulation.

Muscle enzymes such as LDH, AST and ALT increase after capturing (Sánchez et al. 2002), however, rough manipulation or fixation, yet gentle handling does not lead to changes in the concentration of these enzymes (Melillo 2007). These enzymes can be elevated after muscle damage and blood sampling coupled with restrictive activities, but they can also be increased by haemolysis of the sample (Washington and Van Hoosier 2012). Haemolytic samples were not reported by the laboratories, though.

The results of cortisol and corticosterone were lower than known basal values. We assumed that the morning samples would be lower but still measurable. Chronic elevation of glucocorticoid hormones were not proven after repeated exposure during lessons in the experimental as well in the control group. In our study the average manipulation and sampling time was 7 min per one rabbit, from the opening of the cage to the return there. The response to the stress usually takes about 3-5 min after exposure to the stressor (Romero 2004) and the level of elevation of glucocorticoids is individual and also depends on the type of stressor (de Kloet et al. 2005). It was expected that repetitive stress would affect these levels in the long term.

If there was an increase in the concentrations of these hormones in blood due to manipulation (acute stress), we were not able to detect it.

In summary, our study showed significant changes in the experimental group compared to the control group. However, these indices are within the reference range established for the rabbit (Vella and Donnelly 2012; Knotkova et al. 2017) The habituation process during the semester also had some influence, because the repeated process during lessons stimulated the HPA less, and subsequent reactions were milder (Grissom and Bhatnagar 2009). Good overall health was maintained. The results indicate that the effects of stress were at a tolerable level. The use of a large number of rabbits during education is not ideal but this system allows for students to gain knowledge and skills needed in follow-up disciplines without exhausting the rabbit. Thanks to the rotation of the rabbits, rest and partial regeneration were also possible.

\section{Acknowledgement}

The study was supported by the IGA VFU 122/2017 FVL.

\section{References}

Armario A, Marti O, Molina T, de Pablo J, Valdes M 1996: Acute stress markers in humans: response of plasma glucose, cortisol and prolactin to two examinations differing in the anxiety they provoke. Psychoneuroendocrinology 21: $17-24$ 
Breinekova K, Svoboda M, Smutna M, Vorlova L 2007: Markers of acute stress in pigs. Physiol Res 56: $323-329$

Cabezas S, Blas J, Marchant TA, Moreno S 2007: Physiological stress levels predict survival probabilities in wild rabbits. Horm Behav 51: 313-320

Castelhano-Carlos MJ, Baumans V 2009: The impact of light, noise, cage cleaning and in-house transport on welfare and stress of laboratory rats. Lab Anim-UK 43: 311-327

de Kloet ER, Sibug RM, Helmerhorst FM, Schmidt MV 2005: Stress, genes and the mechanism of programming the brain for later life. Neurosci Biobehav R 29: 271-281

Elwasife K, Aziz IA, Shabat M, Shahwan O, El Hamidi AM 2015. Effects of noise on rabbit's blood. European Journal of Biophysics 3: 10-13

Everds NE, Snyder PW, Bailey KL, Bolon B, Creasy DM, Foley GL, Rosol TJ, Sellers T 2013: Interpreting stress responses during routine toxicity studies: a review of the biology, impact, and assessment. Toxicol Pathol 41: 560-614

Grissom N, Bhatnagar S 2009: Habituation to repeated stress: get used to it. Neurobiol Learn Mem 92: 215-224

Kalaba ZM 2012: Physiological response and stress indicators of California rabbits under intensive conditions in Egypt. Asian J Poultry Sci 6:65-78

Knotkova Z, Haupman K, Jekl V 2017: Laboratorní parametry. In: Knotek Z (Ed.): Nemoci zvířat zájmových chovů: drobní savci. Profi Press, Praha, pp. 280-284

Melillo A 2007: Rabbit clinical pathology. J Exot Pet Med 16: 135-145

Möstl E and Palme R 2002: Hormones as indicators of stress. Domest Anim Endocrin 23: 67-74

Okab AB, El-Banna SG, Koriem AA 2008: Influence of environmental temperatures on some physiological and biochemical parameters of New-Zealand rabbit males. Slovak J Anim Sci 41: 12-19

Romero LM 2004: Physiological stress in ecology: lessons from biomedical research. Trends Ecol Evol 19: 249-255

Rosenthal KE 2000: Ferret and Rabbit Endocrine Disease Diagnosis. In: Fudge AM (Ed.): Laboratory Medicine: Avian and Exotic Pets, Saunders, Philadelphia, pp. 319-324

Sánchez O, Arnau A, Pareja M, Poch E, Ramírez I, Soley M 2002: Acute stress-induced tissue injury in mice: differences between emotional and social stress. Cell Stress Chaperon 7: 36-46

Składanowska-Baryza J, Ludwiczak A, Pruszyńska-Oszmałek E, Kołodziejski P, Bykowska M, Stanisz M 2018: The effect of transport on the quality of rabbit meat. Anim Sci J 89: 713-721

Szeto A, Gonzales JA, Spitzer SB, Levine JE, Zaias J, Saab PG, Schneiderman N, McCabe PM 2003: Circulating levels of glucocorticoid hormones in WHHL and NZW rabbits: circadian cycle and response to repeated social encounter. Psychoneuroendocrino 29: 861-866

Vella D, Donnelly TM 2012: Basic anatomy, physiology and husbandry. In: Quesenberry KE, Carpenter JW (Eds.): Ferrets, Rabbits, and Rodents: Clinical Medicine and Surgery. Elsevier, St. Louis, Missouri, 177 p.

Washington IM, Van Hoosier G 2012: Clinical biochemistry and hematology. In: Suckow MA, Stevens KA, Wilson RP (Eds): The Laboratory Rabbit, Guinea Pig, Hamster, and Other Rodents. Waltham, MA: Academic Press/Elsevier. American College of Laboratory Animal Medicine series, pp. 70-75

Wei C, Zhou J, Huang X, Li M 2008: Effects of psychological stress on serum iron and erythropoiesis. Int J Hematol 88: 52-56 